\title{
Techno-Economic Analysis and Performance Evaluation of 25 MW Solar PV Power Plant in Actual Environmental Condition in India
}

\author{
Neha Bansal, Gajendra Singh
}

\begin{abstract}
This paper presents study, identification and evaluation of causes and impact of various degradation modes and environmental conditions on performance of a utility scale grid connected solar PV plant located in remote location in India. Degradation of solar PV modules results in considerable loss in energy yield of overall estimated plant generation. The research includes degradation analysis of $25 \mathrm{MW}$ Roha Dyechem amorphous Si solar PV plant, Charanka, Patan, Gujarat under varying climatic conditions. Some of the well qualified modules were found to degrade in outdoor exposure for more than 7 years. Glass breakage, hot spots, backsheet puncture, micro-delamination, corrosion of cell edges, snail trails, Digital Process Control Board (DPCB) failure, moisture ingression, soiling losses etc. were among the main faults observed in fielded PV modules. A comparative analysis is presented between the simulated, computed and practically measured and recorded field data for drawing important conclusions.
\end{abstract}

Keywords: Performance analysis; Degradation; LCOE; Performance ratio; PVsyst simulation.

\section{INTRODUCTION}

Electricity generation from renewable energy technologies will account for over $40 \%$ by 2040 (IEA). India has set world's largest renewable energy expansion target of 175 GW by year 2022 (MNRE). Solar energy generation is essential in reducing energy and environment related problems mainly $\mathrm{CO} 2$ emissions ( $\mathrm{Li}$ et al., 2018). In last decade, major part of research activities focused on reliability of PV installations and guaranteed lifetime output via constant PV plant monitoring, identifying and quantifying performance loss and failure mechanism (Livera et al., 2019). PV modules are rated w.r.t. Standard Test Conditions (STC), therefore when operated in real environmental conditions, wide variation is observed in the performance parameters (Poortmans et al., 2015). Long term performance studies will increase system yield and result in reduced failures in PV power plant. Degradation analysis and Reliability of PV modules are important factors in maintaining operation of solar PV plants for projected lifetime of 25 to 30 years (Allouhi et al., 2019). The annual

Revised Manuscript Received on July 22, 2019.

Neha Bansal, PhD Research Scholar, Sharda University, Greater Noida, India

Dr. Gajendra Singh, Dean- academics, ABES Engineering College, Ghaziabad,India power degradation rate is one of the key parameter in performance assessment of installed PV plant and is greatly influenced by various environmental parameters such as available solar irradiation, temperature, humidity, wind velocity and dust. For performance evaluation, on-site experimental assessment is required which not only helps in quantifying long term behavior of PV system but is also essential for more accurate modelling of installed PV plant (Martinez et al., 2019). Loss of performance has serious impact on the total energy generation of plant. The current study includes identification, quantification and analysis of all degradation effects and faults observed in fielded PV modules, causes of failures or faults observed, hot climatic effects, variation in performance parameters as per varying solar radiation intensity, temperature, cleaning methods, cleaning frequency etc. and soiling studies. 
Techno-Economic Analysis and Performance Evaluation of 25 MW Solar PV Power Plant in Actual Environmental Condition in India

\begin{tabular}{|c|c|}
\hline Nomenclature & \\
\hline Abbreviation & Symbols \\
\hline PV Photovoltaic & a-Si Amorphous silicon \\
\hline DPCB Digital Process Control Board & $\mathrm{CO}_{2} \quad$ Carbon dioxide \\
\hline IEA International Energy Alliance & mc-Si Mono-crystalline silicon \\
\hline MNRE Ministry of New and Renewable Energy & pc-Si Poly-crystalline silicon \\
\hline LCOE Levelized Cost of Electricity & Voc Open Circuit Voltage \\
\hline NPV Net Present Value & Isc Short Circuit Current \\
\hline NCPRE National Centre for Photovoltaic Research \& Education & Vm Maximum Voltage \\
\hline NISE National Institute of Solar Energy & Im Maximum Current \\
\hline IEC International Electro-technical Commission & Pm Maximum Power \\
\hline EVA Ethylene Vinyl Acetate & Tmod Module Temperature \\
\hline FF $\quad$ Fill Factor & Tamb Ambient Temperature \\
\hline PLF Plant Load Factor & $\mathrm{Y}_{\mathrm{R}}$ Reference Yield \\
\hline APFC Automatic Power Factor Control & Final Yield \\
\hline PR Performance Ratio & Available plane of array insolation \\
\hline CUFCapacity Utilization Factor & $\begin{array}{ll}\mathrm{G}_{0} & \text { Reference Irradiance at STC }\end{array}$ \\
\hline STC Standard Test Conditions & Actual AC Output Energy \\
\hline FMECA Failure Mode, Effect and Criticality Analysis & Rated PV array capacity \\
\hline
\end{tabular}

\section{LITERATURE SURVEY}

PV technology investment can be evaluated using (i) LCOE and (ii) NPV method (Bianchini et al., 2016). Site location, design parameters, right installation and regular maintenance are essential in improving the performance of PV plant and making it economically viable source of energy (Singla et al., 2016). The recorded and calculated yields can be used for assessment of different performance indices (Allouhi et al., 2019). The Reference $\left(Y_{R}\right)$ and Final $\left(Y_{F}\right)$ energy yield, Capacity Utilization Factor (CUF), Performance Ratio (PR) and levelized cost of electricity (LCOE) are important performance parameters of grid connected solar PV power plants.

The Reference and Final yield can be calculated using the equations (1) and (2).

Reference Yield $Y_{R}=\frac{\text { Measured in-plane solar insolation }}{\text { Reference Irradiance }}=$ $\frac{G P O A}{\text { GO }}$ (1)

Where,

$\mathrm{G}_{\mathrm{POA}}=$ Available plane of array insolation in $\mathrm{Wh} / \mathrm{m}^{2}$

$\mathrm{G}_{0}=$ Reference Irradiance at STC $\left(1000 \mathrm{~W} / \mathrm{m}^{2}\right)$

Final Yield $\mathrm{Y}_{\mathrm{F}}=\frac{\text { Actual AC Output Energy }}{\text { Rated PV Array Capacity }}=\frac{\mathbb{E} \text { AC }}{\text { p rated }}$

Where,

$\mathrm{E}_{\mathrm{AC}}=$ Actual AC Output Energy in $\mathrm{kWh}$

$\mathrm{P}_{\text {rated }}=$ Rated PV array capacity in $\mathrm{kW}$
The PR is the ratio of Final yield to Reference yield and depends upon irradiation intensity, ambient and module temperature, PV module degradation, reflection losses, wiring and mismatch losses, component failures, inverter efficiency etc (Martinez et al., 2019). LCOE is used to determine the most economical solar PV plant. It is the net present value of all costs over the project lifetime divided by total energy generation from plant (Martinez et al., 2019). Deeper understanding of faults and degradation modes and the extent to which they affect the efficiency and result in reduced electricity generation is important for early faults detection and prevention thereby reducing LCOE and payback period (Bianchini et al., 2016).

The performance of six large solar PV plants with different technology (mc-Si, pc-Si) and mounting topology (fixed, single and dual axis tracking) in Spain with daily, monthly and yearly variation in PR distribution is evaluated and analyzed by (Martinez et al., 2019). In Ghana, on 2019, Masah et al. conducted outdoor performance assessment of 2.5 MW solar PV plant from 2013 to 2016 and evaluated various performance indices such as PR, LCOE, capacity factor, discounted payback period, energy fed into grid and reduction in $\mathrm{CO} 2$ emission. In Morocco, on 2018, Aarich et al. compared performance of three grid connected $\mathrm{Si}$ based PV technologies (mc-Si, pc-Si and a-Si $/ \mu \mathrm{c}-\mathrm{Si}$ ) for 32 months of outdoor exposure using $\mathrm{AC}$ yields or DC performance ratios and presented that in winter, mc-Si yield more than $\mathrm{pc}-\mathrm{Si}$ followed by a-Si/ $\mu \mathrm{c}-\mathrm{Si}$

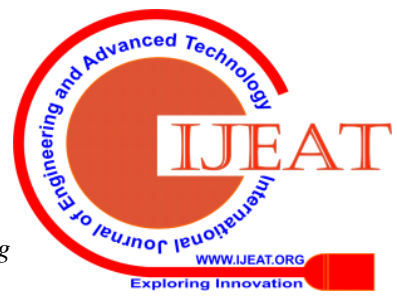




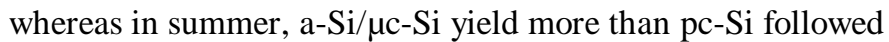
by $\mathrm{mc}-\mathrm{Si}$. The performance of grid connected $6.4 \mathrm{kWp}$ rooftop solar PV system using various simulation softwares PV*SOL, SolarGIS, SISIFO and PVGIS was analyzed by (C. Dondariya et al., 2018). In USA, Singh et al. in 2013 at Arizona State University, Photovoltaic Reliability Laboratory (ASU-PRL) did performance analysis of 1900 modules of a solar PV plant from six different manufactures aged between 12 and 18 years and measured the overall average power degradation rate ranging from $0.6 \%$ /year to $2.5 \%$ per year. In 2015 , Shrestha et al. at ASU-PRL evaluated failure and degradation modes of 5900 c-Si modules fielded for 6 to 16 years of 3 different PV plants using Failure Mode, Effect and Criticality Analysis (FMECA), a statistical reliability tool under hot dry desert climate of Arizona and determined dominant failure modes in modules from both safety and performance perspective. In 2013, a meeting held by "High powered Task force under Jawaharlal Nehru National Solar Mission (JNNSM) for solar photovoltaics" requested National Centre for Photovoltaic Research and Education (NCPRE) together with National Institute of Solar Energy (NISE) to conduct All-India survey of PV module degradation. In this survey, they inspected $63 \mathrm{PV}$ modules across 26 different sites in 5 climatic zones of India and observed that power degradation was significant in hot zones, reduction in short circuit current dominated in hot and dry zone whereas reduction in fill factor contributed significantly in hot and humid zones. In 2014 survey, NCPRE and NISE inspected 1148 modules of 6 different technology at 51 sites in 6 climatic zones of India and observed that annual degradation rate varied from $0.6 \%$ /year to more than $4 \%$ year and concluded that modules in hot climate degrade faster than modules in non-hot climate. In 2016 survey, they inspected 925 modules of 6 different technology aging 1 to 25 years at 37 sites in 6 climatic zones of India and observed that solder bond fatigue was the most common defect with highest concern while encapsulant discoloration was the most common degradation mode in major climatic zones. In India, on 2018, Bajpai et al. did performance evaluation of $5 \mathrm{~kW}$ rooftop grid connected PV plant based on various performance parameters like reference, array and final yield, PV module, inverter and system efficiency, PR, capacity factor and also studied the effect of temperature in different seasons on the performance of the plant. Kumar et al. presented in 2017, at Chennai, the performance simulation of $100 \mathrm{~kW}$ grid connected pc-Si PV system using PVsyst software and conducted the study for evaluating the feasibility of installing a PV system to supply electrical load of an educational institute. In Canada, Garni et al. in 2017 at Concordia University, Montreal did techno-economic feasibility analysis of grid connected PV system with different tracking configuration and time adjustments using Hybrid Optimization of Multiple Energy Resources (HOMER) software. Thus, major part of current research activities were focused on performance evaluation and reliability assessment of grid connected PV systems in different countries in the world.

The IEC 61724 documentation consists of the methodology for evaluating the performance of grid connected PV systems (Satsangi et al., 2018). The performance of solar PV modules with 25 years lifetime and performance warranty of $80 \%$ at the end of 25 years declines more than specified range (Singh et al., 2013) and various degradation/failure modes are being observed predominantly hotspots, thermal and mechanical damage, corrosion of cell edges and inter-connect, soiling, solder bond fatigue etc. when exposed to actual environmental conditions (UV exposure, high temperature, relative wind velocity, humidity and soiling). Early detection and diagnosis of failures is important to reduce operation and maintenance $(\mathrm{O}$ $\&$ M) cost and system downtime (Livera et al., 2019).

\section{METHODOLOGY}

For the analysis and evaluation of performance of solar PV power plants in actual environmental conditions (hot and dry climate), 25 MW DC Roha Dyechem Pvt. Ltd. Solar PV power plant, Patan operational since 7 years in remote location of Gujarat, was thoroughly studied and evaluated. Real monitored SCADA data and practically measured field data for a period of seven years from 2012 to 2018 has been collected and analyzed for plant performance calculations. Data collection from this power plant include system layout, module type, site conditions, actual generation, solar irradiation data, sunshine duration, type of mounting system, nameplate specifications (Voc, Isc, Vm, Im, FF (\%) and Pm), module and ambient temperature, system losses and count data of failure modes. In order to validate and compare the estimated energy generation of installed PV system, PVSYST simulation was carried out for determining daily and monthly energy yields, normalized productions, PR, efficiency and various system losses based on hourly meteorological values of incident solar irradiation, ambient temperatures and wind velocities. Actual generation data in MWh and estimated output from solar power plant is analyzed for plant performance calculations. The specifications of the inspected solar PV power plant is tabulated in Table 1.

\begin{tabular}{ll}
\multicolumn{2}{c}{ Classification } \\
\hline Site & $25 \mathrm{MW}$ plant Charanka, Patan \\
\hline Latitude, Longitude and Altitude & $23.91^{\circ} \mathrm{N} 71.18^{\circ} \mathrm{E} 16$ meters \\
Climatic Zone & Hot and Dry \\
Mean monthly (May and June) Max Temp $\left({ }^{\circ} \mathrm{C}\right)$ & $>40$ \\
Relative Humidity $(\%)$ & $>50$
\end{tabular}


Techno-Economic Analysis and Performance Evaluation of 25 MW Solar PV Power Plant in Actual Environmental Condition in India

Max. Irradiation Intensity $\left(\mathrm{W} / \mathrm{m}^{2}\right)$

No. of modules visually inspected
1200 to 1400

6800 a-Si modules

\section{SYSTEM DESCRIPTION AND CONFIGURATION}

In this section, description of the inspected solar PV power plant, data collection, plant details and calculations is presented.

\subsection{Description of 25 MW DC Roha Dyechem Solar PV power plant}

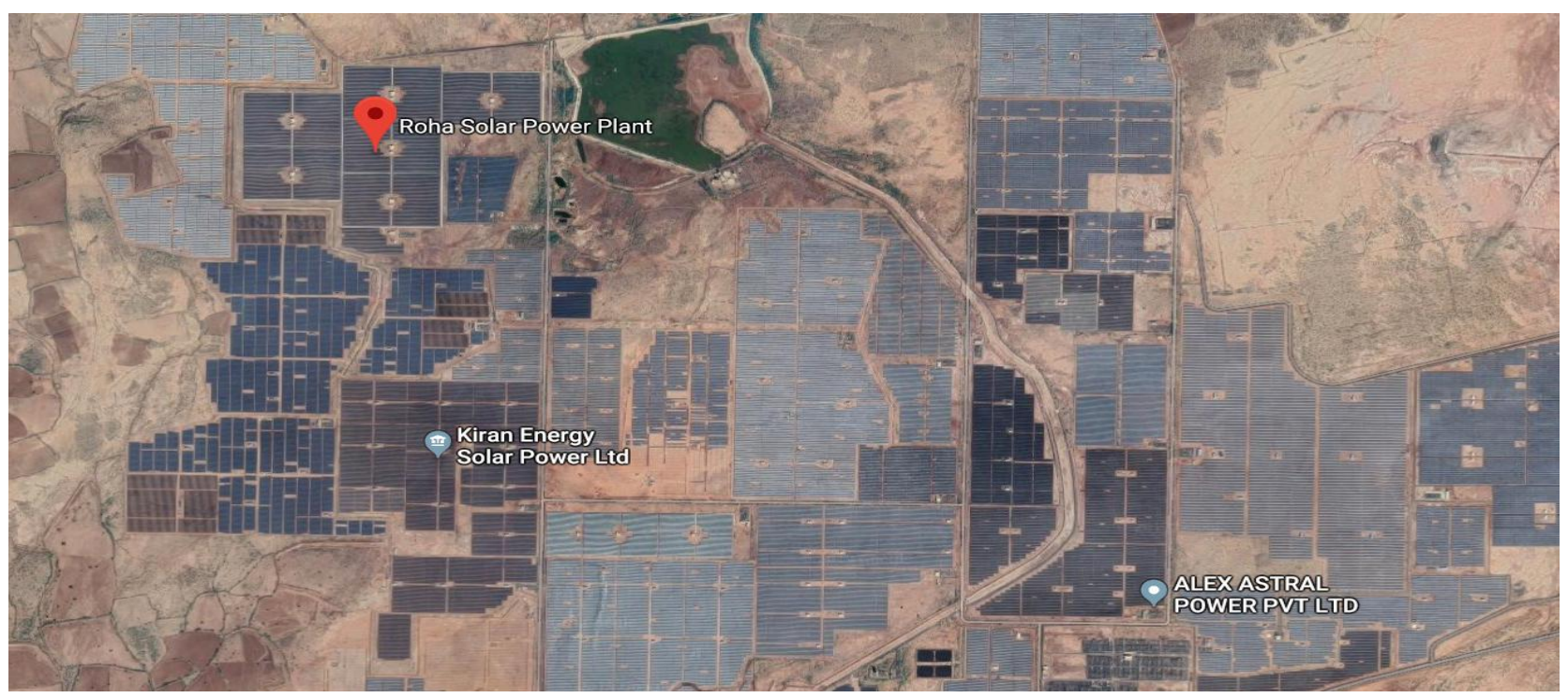

Figure 1. Location and Satellite view of 25 MW Roha Dyechem solar PV power plant Charanka, Patan, Gujarat.

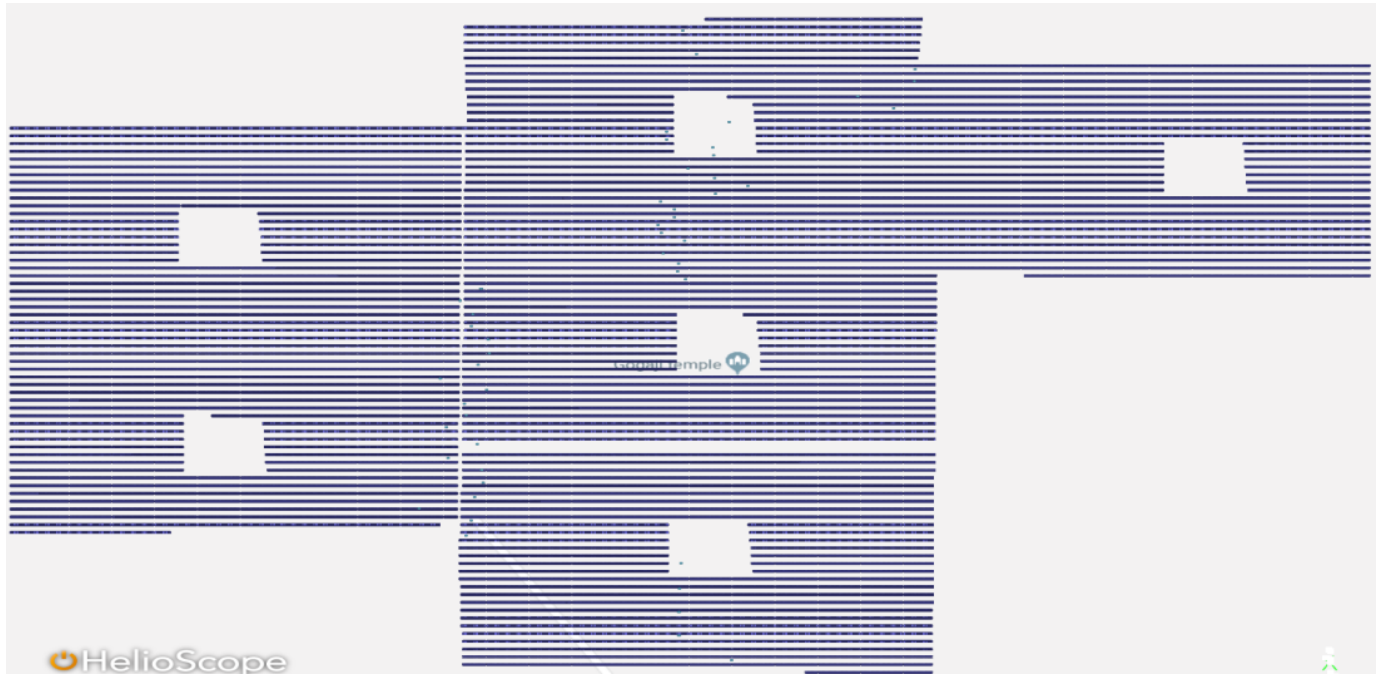

Figure 2. Simulated layout of 25 MW Roha Dyechem solar PV power plant Charanka in Helioscope software.

The 25 MW plant shown in Fig. 1 is among 20 co-located solar PV plants in Gujarat solar park, Charanka village, Patan district. The plant consists of total seven blocks, six blocks of $4 \mathrm{MW}$ capacity $(6 * 4=24 \mathrm{MW})$ and one block of $1 \mathrm{MW}$ (Total: $24+1=25 \mathrm{MW}$ ) capacity. One $4 \mathrm{MW}$ block was centralized. Total 6400 structures, one structure consists of 27 modules, 9 modules in series and 3 such series in parallel $(9 * 3=27$ modules), 10 or 11 Arrays connected to one master junction box. The plant consists of total 1, 72,422 thin films a-Si modules from Nex Power of 145 watts. The choice of thin film technology was made owing to reduced cost and reduced losses, losses based on temperature are $0.5 \mathrm{~W} /{ }^{\circ} \mathrm{C}$ for $\mathrm{c}-\mathrm{Si}$ and $0.25 \mathrm{~W} /{ }^{\circ} \mathrm{C}$ for thin films. The latitude of location is $23.9^{\circ} \mathrm{N}$ and the Plant Load Factor (PLF) is $20 \%$ (Range: 18 to $20 \%$ ). RO distilled water with water tank capacity of 5000 liters is used for cleaning modules so that there is no scaling due to salt deposition. The modules were cleaned in early morning

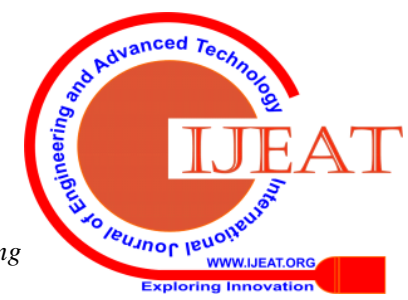


because noon and afternoon cleaning may result in thermal cracks in modules. The temperature of modules observed were around $45{ }^{\circ} \mathrm{C}$ to $50{ }^{\circ} \mathrm{C}(\mathrm{Tmod}=\mathrm{Tamb}+5$ $\left.{ }^{\circ} \mathrm{C}\right)$. The plant consists of total 50 centralized three phase inverters from Satcon, one inverter capacity of $500 \mathrm{KW}$.
Automatic Power Factor Control (APFC) is employed with power factor of 0.99. $265 \mathrm{~V} \mathrm{AC}$ being stepped up to $11 \mathrm{KV}$ via total $25,1.25 \mathrm{MVA}$ transformers, $11 \mathrm{KV}$ to 66 $\mathrm{KV}$ via 27.50 MVA main transformer then given to grid as shown in Fig. 4.

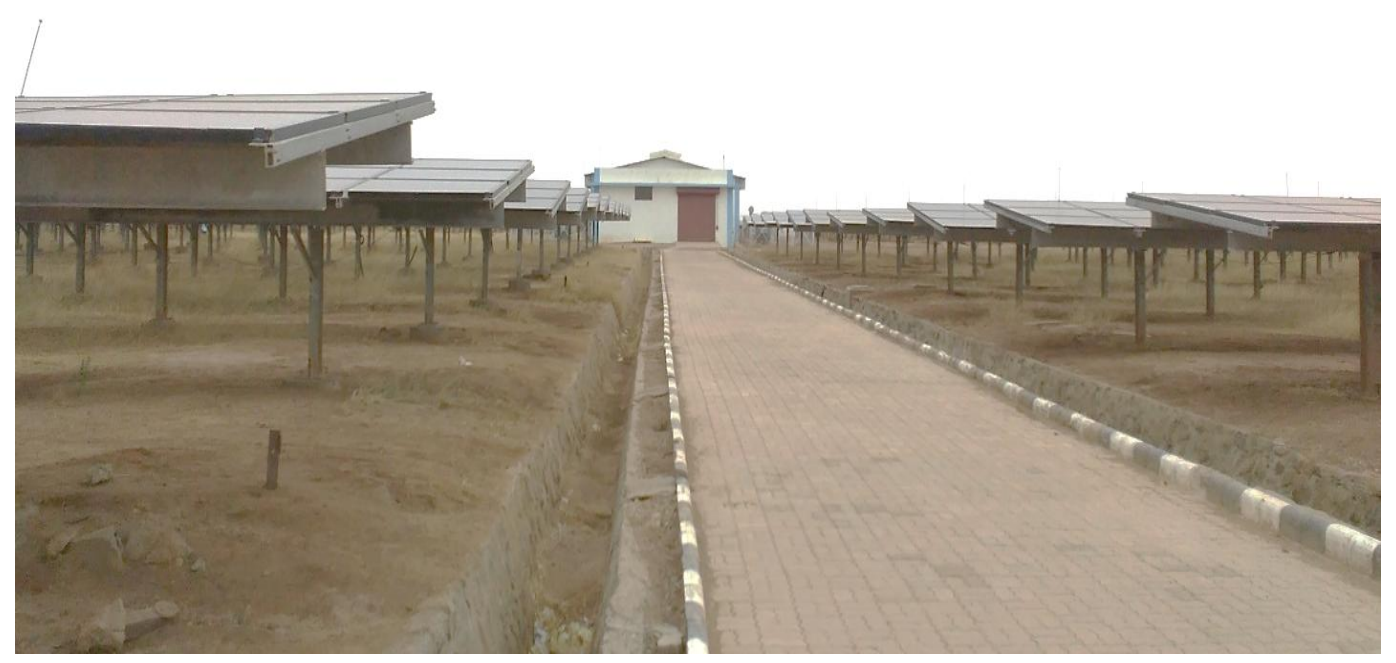

Figure 3. 25 MW DC Roha Dyechem solar PV power plant commissioned at Charanka, Patan District, India (original image taken at plant site).

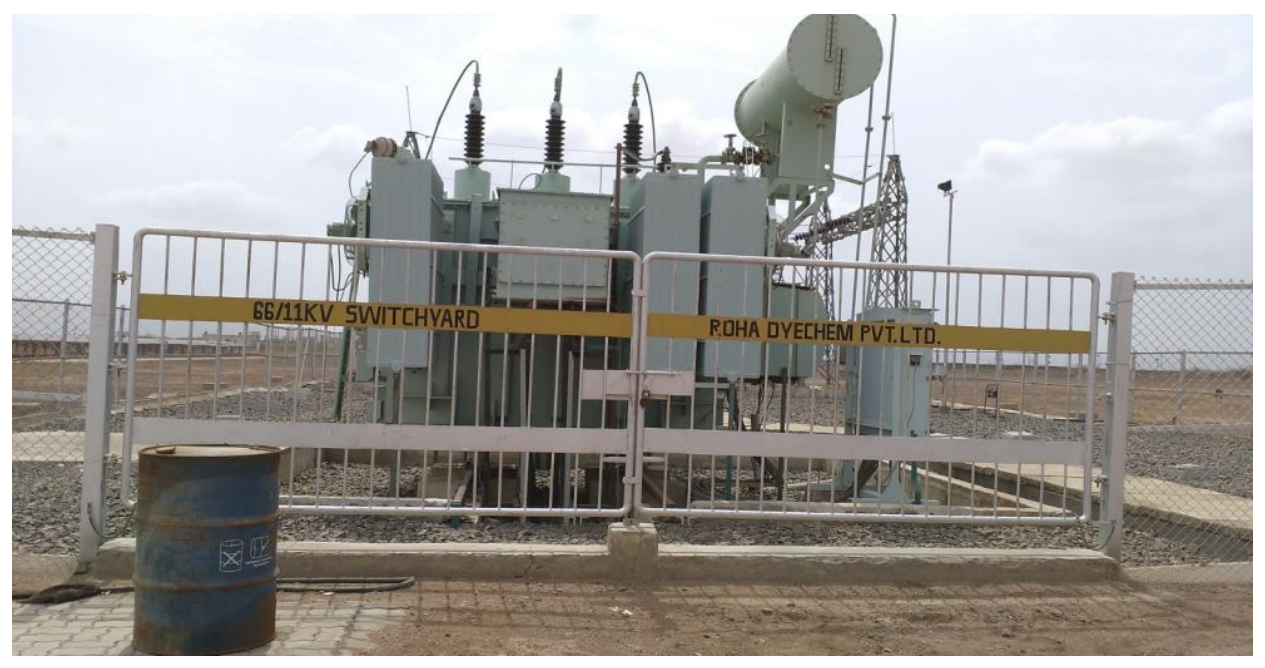

Figure 4. $11 \mathrm{KV}$ to $66 \mathrm{KV}$ Main Transformer located in $25 \mathrm{MW}$ power plant (original image taken at plant site).

Seasonal tilt orientation of $5^{\circ}$ in summer from May to August, $13^{\circ}$ in September and April, $35^{\circ}$ from October to March for modules in 25 MW DC Roha Dyechem plant is employed for maximizing electricity generation. Sunshine hours in summers were $12 \mathrm{hrs}$ from $7 \mathrm{AM}$ to $7 \mathrm{PM}$, in winters 8 hours and in monsoon of 4 to 5 hours average.

\section{OBSERVATIONS}

\subsection{Faults observed in 25 MW Solar PV plant: $10 M W$}

Framed a-Si modules plant major faults

5.1.1. Mechanical damage during Installation - modules replaced by Nex power.

Mechanical damage: 15 Modules in one year, replacement cost beared by plant owner.
Instruments available were Meggers for measuring cable faults and clamp meters to measure current and voltage. The annual plant output for $1 \mathrm{MW}$ section is around 17 lakh units, a total of $(17 * 25) 4$ crore 25 lakh units generation per year.

\section{Possible Reasons:}

5.1.1.1. Clamping: Clamp loose due to high winds, clamps open resulting in module damage

5.1.1.2. Structural tilting resulting in bending of modules, rarely observed.

5.1.2. DPCB (Digital Process Control Board) failure 


\section{Condition in India}

Possible reasons may be control board hang, software system failure due to grid fluctuations. Out of failure of total 5 DPCBs till date, two are repaired, the repair is still under research.
Safety hazard, may cause fire.

5.1.4. Hotspots and Glass Breakage

\subsubsection{Connector open}

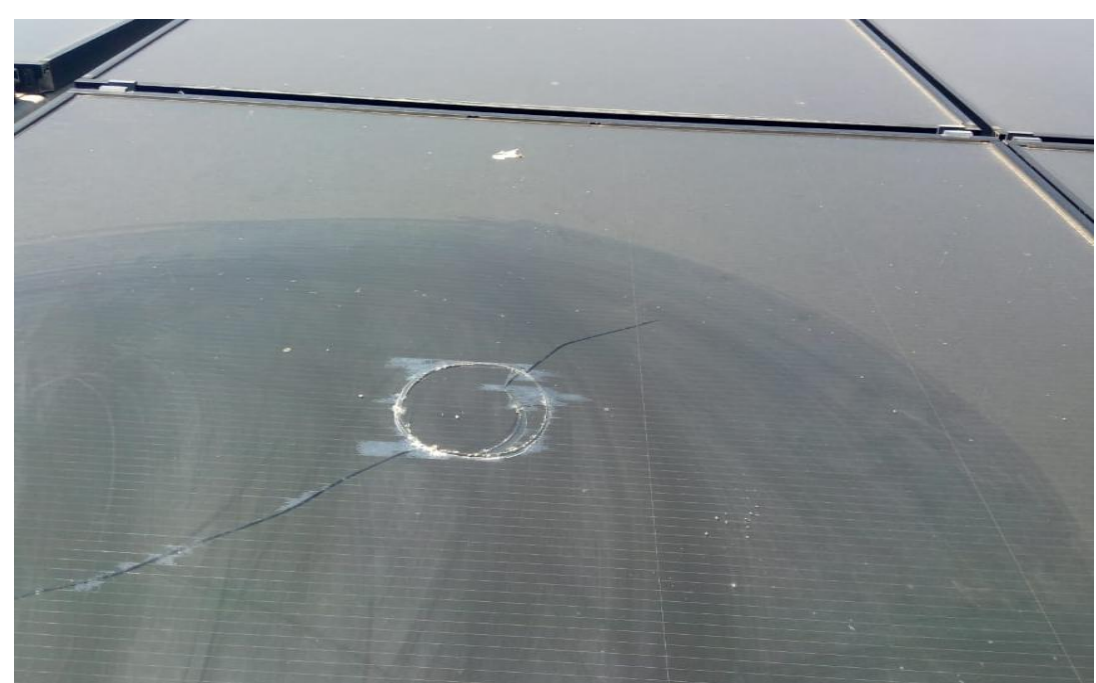

Figure 5. Hotspot and glass breakage observed in fielded PV module in $25 \mathrm{MW}$ solar PV plant (Original image taken at plant site)

\subsubsection{Backsheet Puncture}

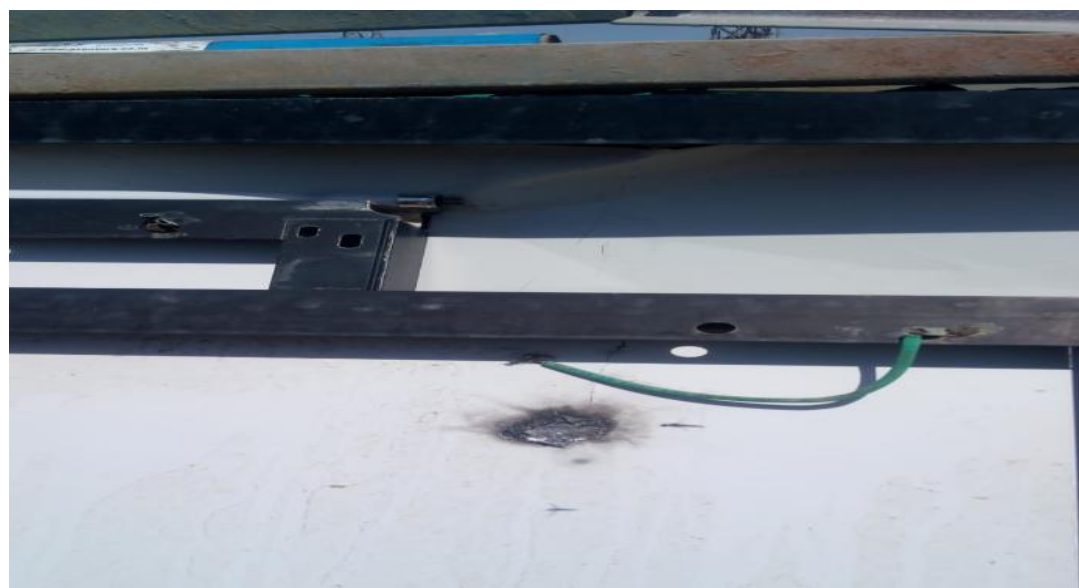

Figure 6. Backsheet puncture observed in fielded PV module in 25 MW solar PV plant (Original image taken at plant site) Backsheet cracking and puncture was observed in few fielded modules around 8 to 10 modules in 25 MW solar PV plant shown in Fig. 6.

5.1.6. Micro Delaminations, Cell cracks and Corrosion of cell edges
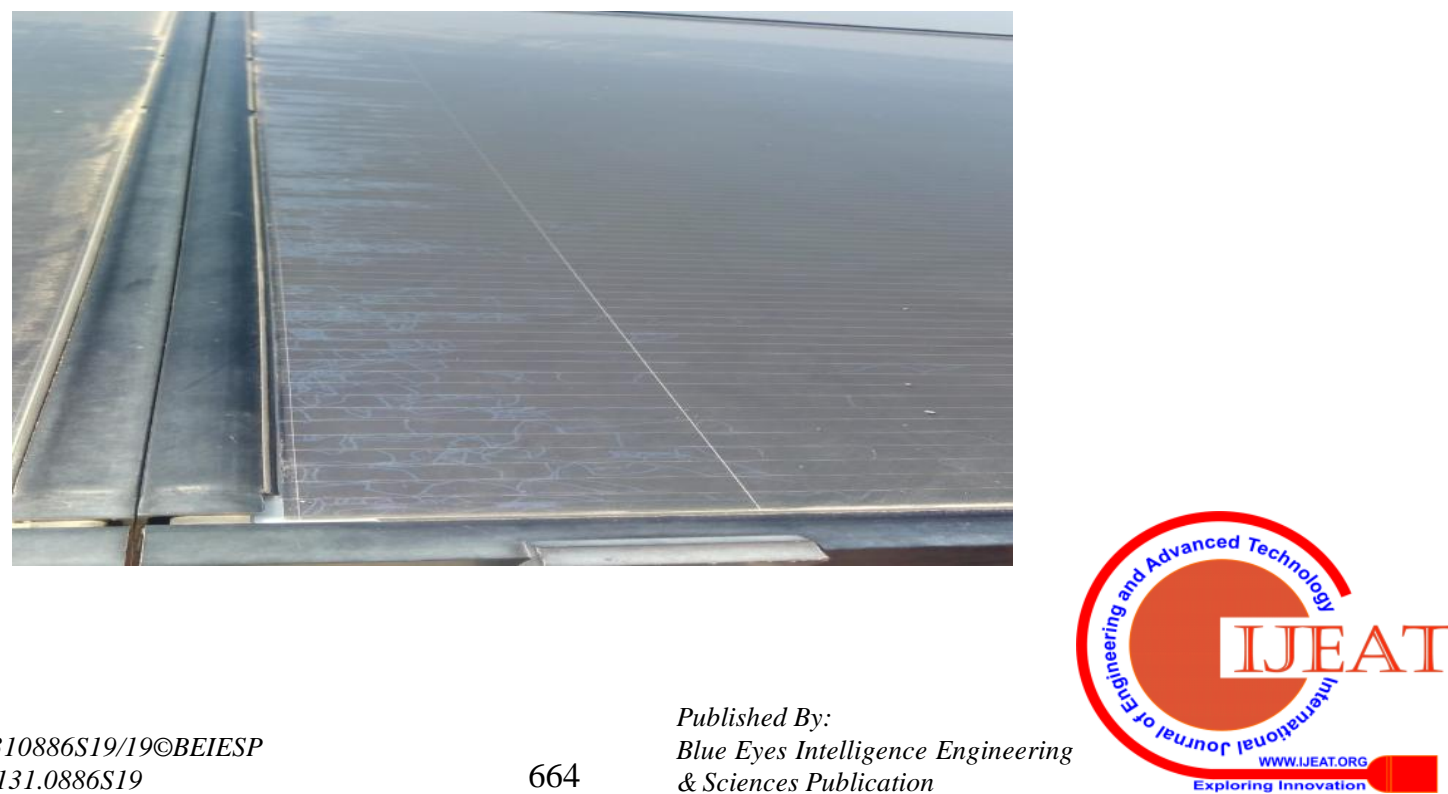
Figure 7. Micro Delaminations, Cell cracks and Corrosion of cell edges observed in fielded PV modules (original image)

5.2. Faults observed in 25 MW Solar PV plant: $15 M W-$ Frameless a-Si modules plant major faults:

5.2.1. Glass Breakage

5.2.2. Moisture Intrusion

5.2.3. Degradation losses (snail trails)

\subsubsection{Soiling losses (Upto $5 \%$ if no cleaning)}

The field images of above mentioned faults i.e. 5.2.1 to 5.2.4 were not taken due to the limitation of visiting the entire $25 \mathrm{MW}$ plant. The faults observed in frameless modules are listed from the enquiry from the plant officials. The annual power degradation loss of fielded PV modules in $25 \mathrm{MW}$ power plant was within $1 \%$ / year.

\section{SIMULATION RESULTS}

6.1. 25 MW Roha Dyechem Solar PV power plant simulation results

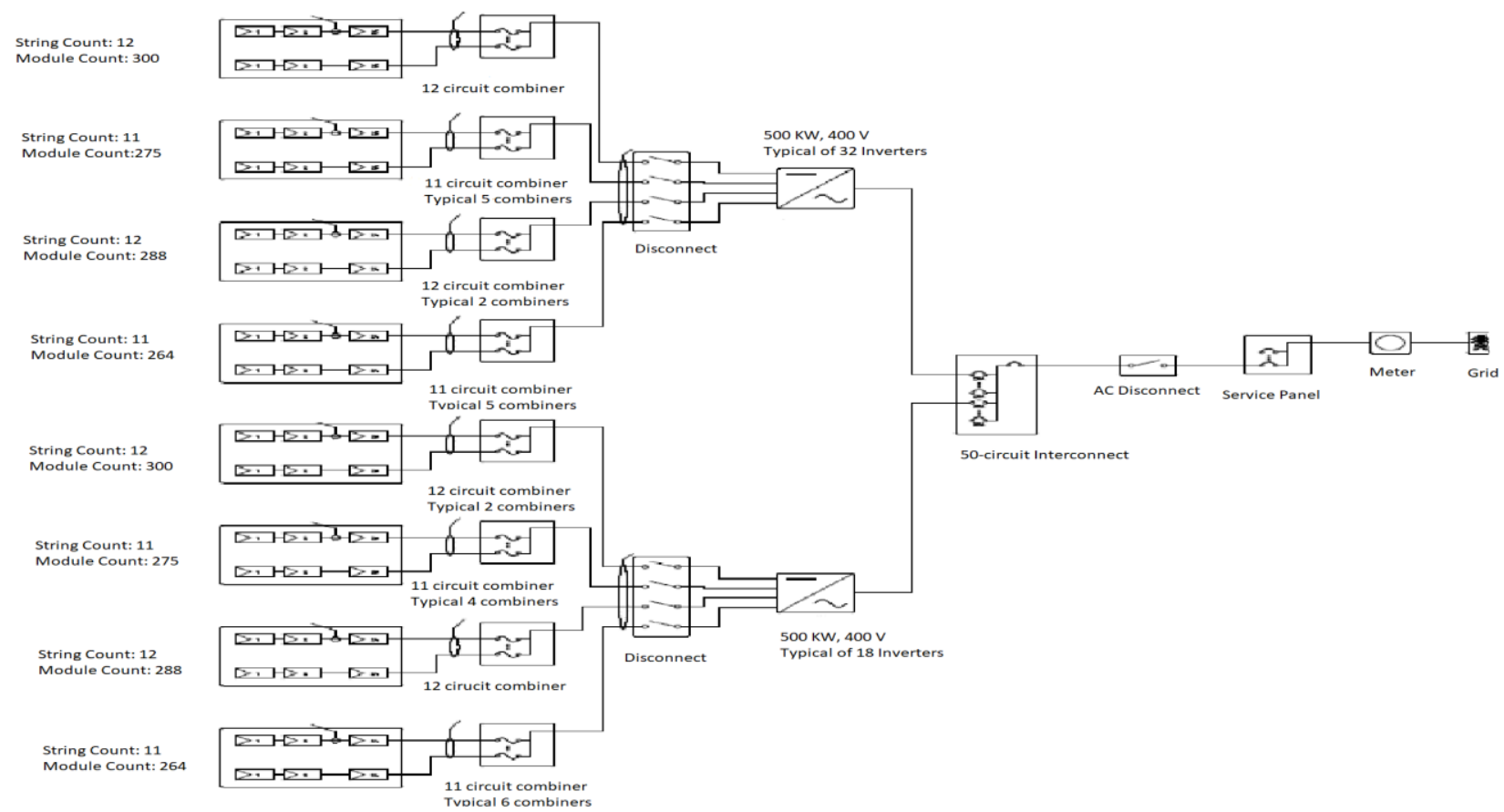

Figure 8. Simulated Single Line Diagram of 25 MW solar PV plant, Charanka, Patan. 
Techno-Economic Analysis and Performance Evaluation of 25 MW Solar PV Power Plant in Actual Environmental Condition in India

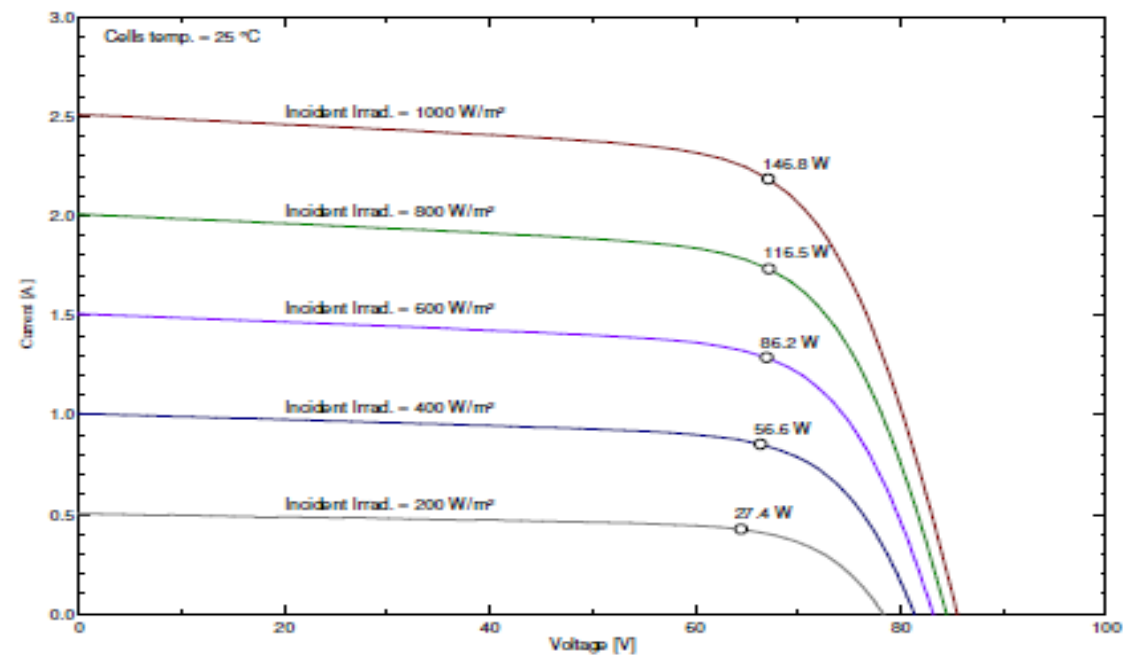

Figure 9. Simulated I-V and Power characteristics of 145 Wp Nex Power a-Si module at STC using PVsyst software

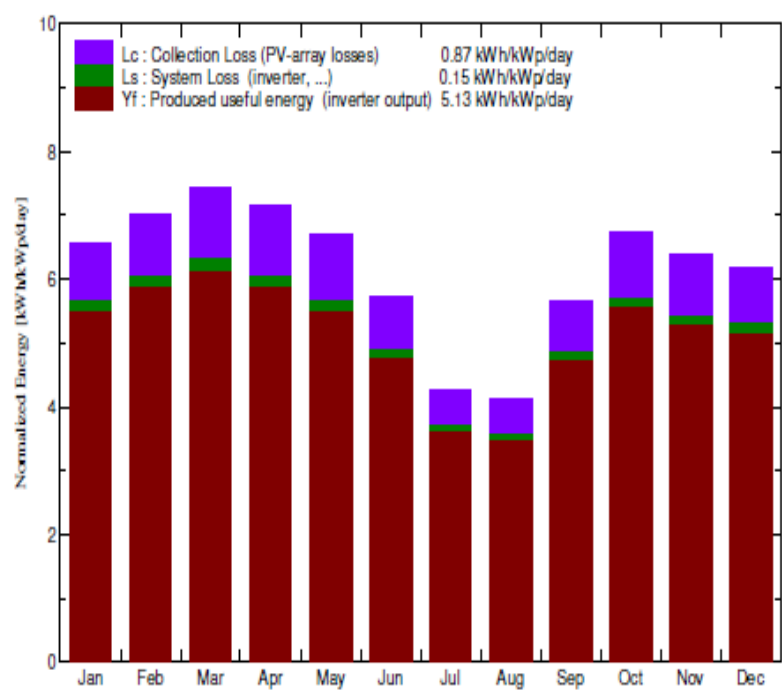

Figure 10. Normalized productions (per installed kWp)

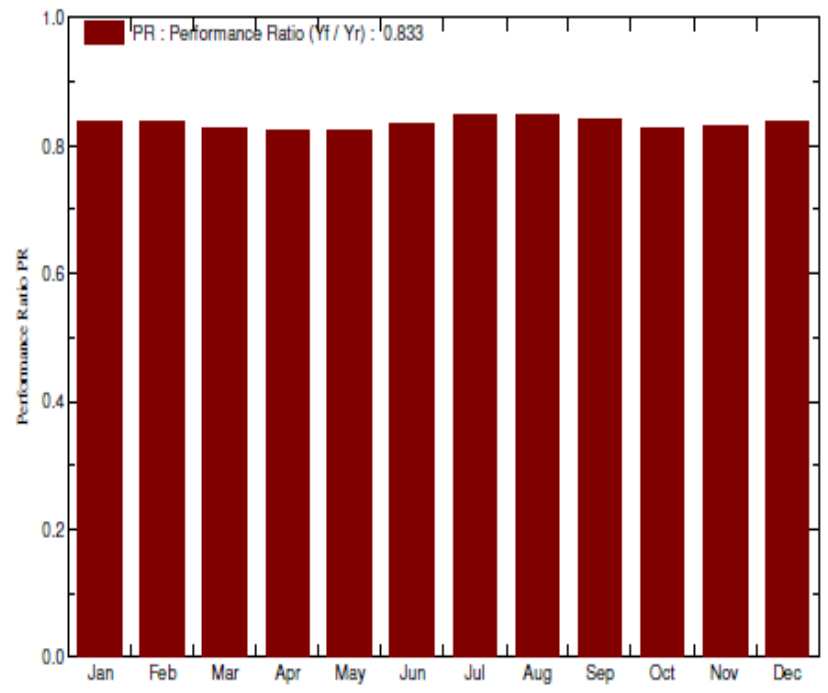

Figure 11. PR $83.3 \%$ (simulated) and $85 \%$ practically measured

\section{RESULTS AND DISCUSSIONS}

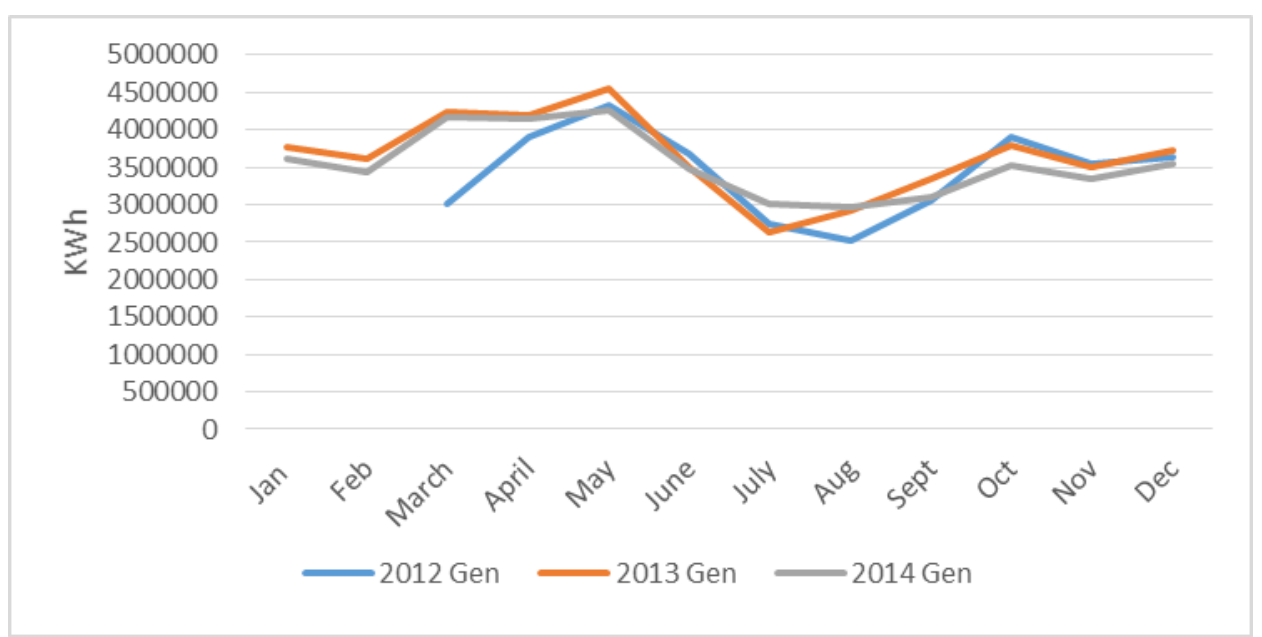

Figure 12. Monthly variation of generation of $25 \mathrm{MW}$ solar PV plant w.r.t. climatic conditions for the years 2012, 2013 and 2014.

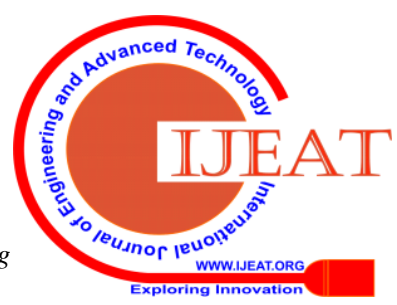




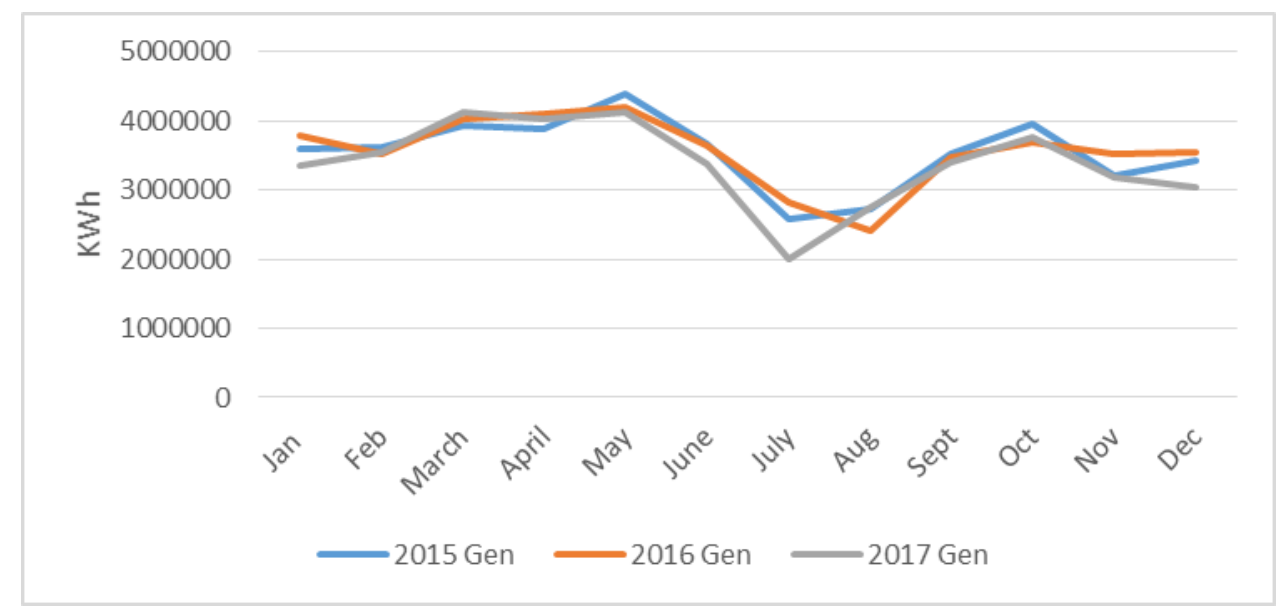

Figure 13. Monthly variation of generation of 25 MW solar PV plant w.r.t. climatic conditions for the years 2015,2016 and 2017.

The variation in consecutive years in annual units generated for $25 \mathrm{MW}$ Roha Dyechem solar PV power plant is represented in Fig. 12 and Fig. 13 wherein the reduction in the monthly electricity generation in the year 2017 was mainly due to less irradiation intensity available and partly due to environmental degradation (mechanical damage due to high winds, snail trails, glass breakage, soiling losses).

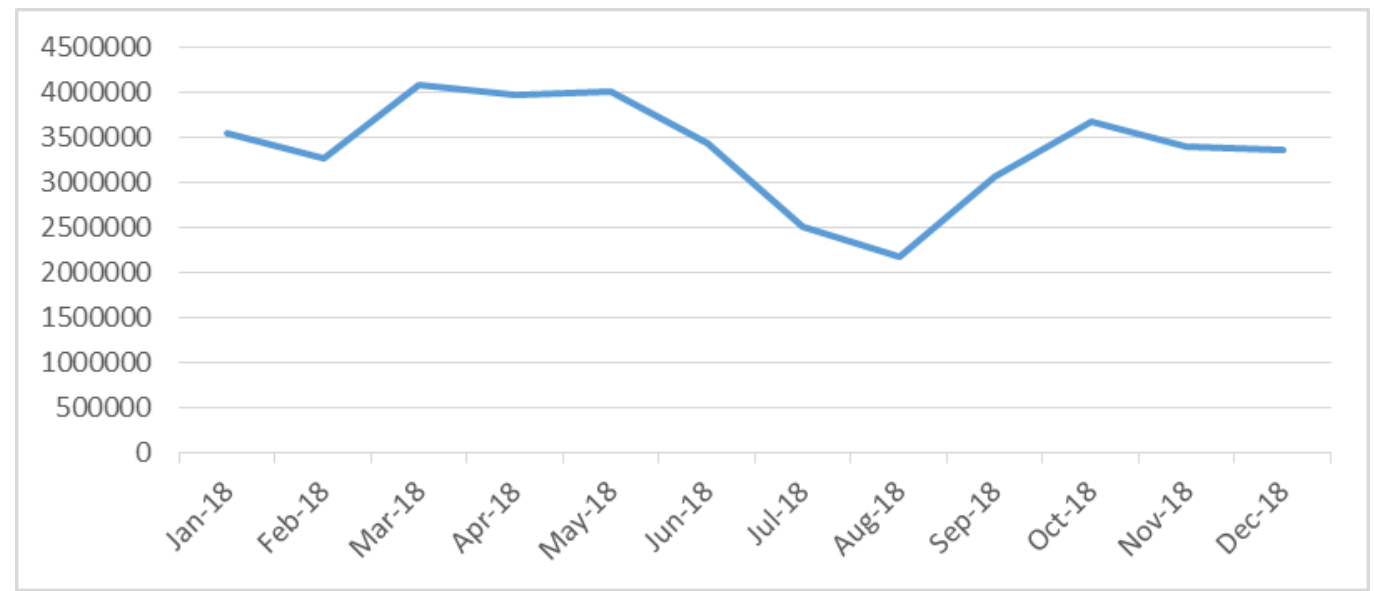

Figure 14. Monthly cumulative generation of $25 \mathrm{MW}$ solar PV plant for the year 2018. (Graph plotted from the data collected

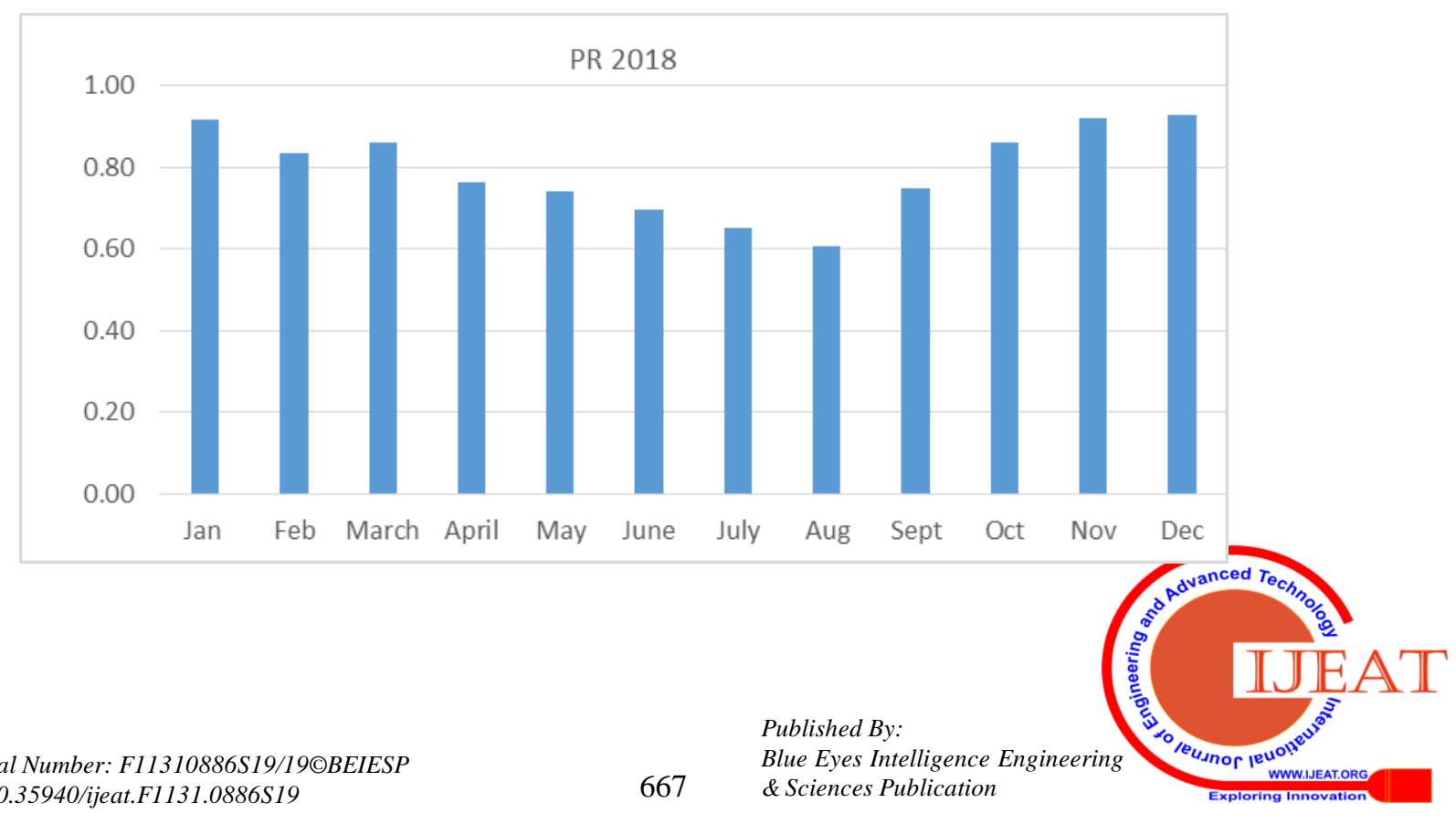


Figure 15. 25 MW Solar PV Plant PR distribution analysis from January to December 2018. (PR calculated from actual field data)

The distribution of monthly PR values calculated for $25 \mathrm{MW}$ plant is shown in Fig. 15. Wide variation is observed in monthly PR values in winter, summer and rainy season with PR values ranging from min. 61\% (due to lower energy generation owing to more rainfall, varying solar irradiation intensity and losses due to elevated module temperature) to max. $93 \%$ with an average of $79 \%$ (calculated from final and reference yields). The estimated average PR value was $83.3 \%$ (using PVSyst simulation) whereas the recorded SCADA value was $80 \%$ (data received from plant official).

The financial and technical analysis of the plant was carried out under varying climatic conditions on annual basis and results obtained are validated with the actual recorded data. Among the various techno-economic and performance evaluation parameters, the Performance Ratio (PR), the Capacity Utilization Factor (CUF), the LCOE and the Payback period of the plant are evaluated using equations (3), (4), (5) and (6).

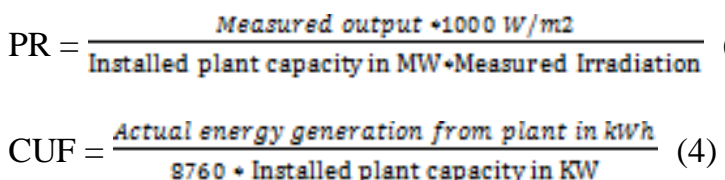

\section{CONCLUSION}

To the best of author's knowledge, there is dearth of performance analysis carried out on utility scale large PV plants in India in literature and that too for several operational years. The present study investigates technical and financial aspects, performance and degradation analysis, LCOE and PR estimation of grid connected PV system with a-Si technology over installation period of more than seven years. The comparison of measured field performance and simulated results communicated in this study show that there is a difference of 1 lakh units generated (16 to 17 lakh units annual generation for $1 \mathrm{MW}$ section) between the simulated and actually measured plant output in $25 \mathrm{MW}$ solar plant owing to various degradation losses observed mainly due to prevalent hot and dry climate, varying solar radiation intensity, module operating temperature, module cleaning frequency (soiling) etc. Global solar irradiation and ambient temperature were the most influencing parameters for reduction in energy generation of the inspected plant. Seasonal trend is observed for inspected ground mounted PV plant with seasonal tilt adjustment where PR values are higher in winter followed by summer and rainy season. The power measurement by portable I-V curve tracer for few modules (new module and field deployed modules) indicated degradation within $1 \%$ per year for thin film a-Si modules despite of snail trails, moisture intrusion, thermal and mechanical damage, micro-delamination, hot spots and soiling losses. The occurrence of various faults pinpoint the need of more research to be carried out in performance evaluation and reliability study of PV plants in varying climatic conditions to prevent premature failures in field,
LCOE $(\mathrm{Rs} / \mathrm{kWh})=\left(\frac{\text { Total Plant Cost }}{\text { Total Generation }}\right)$ over lifetime of the project (5)

The total cost for 25 years include capital cost, interest cost, Operation and Maintenance (O \& M) cost and Replacement cost.

Payback Period $=\frac{\text { Total Installed System Cost }}{\text { Annual units generated } \bullet \text { cost of one unit }}$ (6)

The annual average values of various performance indices calculated are:

(i) CUF - $18.5 \%$

(ii) PR - $80 \%$,

(iii) LCOE - 2.465 Rs/kWh and

(iv) Payback period - 7 years

increase service lifetime and reliability of PV modules.

\section{FUTURE SCOPE}

- To study impact of individual failure mode on performance of fielded PV module.

- How to mitigate severity effects from failure.

- $\quad$ FMECA statistical analysis (Shrestha et al., 2015)

- Reliability analysis

\section{ACKNOWLEDGMENT}

The authors are thankful to Roha Dyechem Pvt. Ltd. for providing permission and technical assistance.

\section{REFERENCES}

[1] International Energy Agency (IEA), World Energy Outlook, 2018. < https://www.iea.org/weo2018/>.

[2] https://mnre.gov.in/

[3] Allouhi A., Saadani R., Buker M.S., Kousksou T., Jamil A., Rahmoune M., 2019. Energetic, economic and environmental (3E) analyses and LCOE estimation of three technologies of PV grid-connected systems under different climates. Solar Energy 178, 25-36.

[4] Satsangi P., Das B., Babu S., Saxena A.K.,2018. Performance analysis of grid interactive solar photovoltaic plant in India. Energy Sustain. Dev. 47, 9-16.

[5] Martinez S. M., Carreton M. C., Escribano A.H., Lazaro E. G., 2019. Performance evaluation of large solar photovoltaic power plants in Spain. Energy Convers. Manage. 183, 515-528.

[6] Livera A., Theristis M., Makrides G., Georghiou G., 2019. Recent advances in failure diagnosis techniques based on performance data analysis for grid-connected photovoltaic systems. Renew. Energy $133,126-143$.

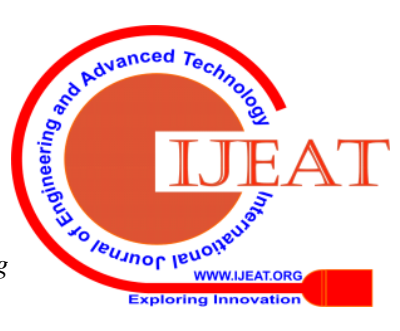


[7] https://www.ncpre.iitb.ac.in. [Report on All-India Survey of Photovoltaic Module Reliability: 2016].

[8] Li C., Zhou D., Zheng Y., 2018. Techno-economic comparative study of grid-connected PV power systems in five climate zones, China. Energy $165,1352-1369$

[9] Aarich N., Raoufi M., Bennouna A., Erraissi N., 2018. Outdoor comparison of rooftop grid-connected photovoltaic technologies in Marrakech (Morocco). Energy \& Buildings 173, 138-149.

[10]Bajpai U., Yadav S., 2018. Performance evaluation of a rooftop solar photovoltaic power plant in Northern India. Energy Sustain. Dev. 43, 130-138.

[11]Dondariya C., Porwal D., Awasthi A., Shukla A. K., Sudhakar K., Bhimte A., 2018. Performance simulation of grid-connected rooftop solar PV system for small households: A case study of Ujjain, India. Energy Reports 4, 546-553.

[12]Bianchini A., Gambuti M., Pellegrini M., Saccini C., 2016. Performance analysis and economic assessment of different photovoltaic technologies based on experimental measurements. Renew. Energy 85, 1-11.

[13]Singh J., Belmont J., Tamizhmani G., 2013, June. Degradation Analysis of 1900 PV modules in a Hot-Dry Climate: Results after 12 to 18 years of field exposure. In: PVSC, 2013. Conference Record of Thirty-nineth IEEE, IEEE, pp. 16-21.

[14]Shrestha S.M., Mallineni J.K., Yedidi K.R., Knisely B., Tatapudi S., Kuitche J., Tamizhmani G., 2015, Jan. Determination of dominant failure modes using FMECA on the field deployed c-Si modules under hot-dry desert climate. IEEE J. Photovolt. 5 (1), 174-182.

https://www.ncpre.iitb.ac.in. [Report on All-India Survey of Photovoltaic Module Reliability: 2014].

[15]Mensah L.D., Yamoah J.O., Adaramola M.S., 2019. Performance evaluation of a utility-scale grid-tied solar photovoltaic (PV) installation in Ghana. Energy Sustain. Dev. 48, 82-87.

[16]Kumar N.M., Kumar M.R., Rejoice P.R., Mathew M., 2017. Performance analysis of $100 \mathrm{kWp}$ grid connected Si-poly photovoltaic system using PVsyst simulation tool. Energy Procedia 117, 180-189.

[17]Vasita J., Shakhiya Q., Modi J., 2017. Feasibility study and Performance evaluation of a grid-connected Rooftop Solar PV system. In: International conference on Information, Communication, Instrumentation and Control (ICICIC), IEEE, 2017 August.

[18]Poortmans J., Voroshaszi E., Deceuninck W., Szlufcik J., 2015, April. Higher Performance and Improved Reliability: key to making photovoltaics the mainstream sustainable electricity generation source of the 21st Century. In: IRPS IEEE International Conference, IEEE, pp. 3E.1.1 - 3E.1.7.

https://www.ncpre.iitb.ac.in. [Report on All-India Survey of Photovoltaic Module Degradation: 2013].

[19]Ishii T., Masuda A., 2017, July. Annual degradation rates of recent crystalline silicon photovoltaic modules. Prog. Photovoltaics: Res. Appl. 25, 953-967.

[20]Singla A., Singh K., Yadav V.K., 2016. Environmental effects on performance of solar photovoltaic module. In: Biennial International Conference on Power and Energy Systems:Towards Sustainable Energy (PESTSE), IEEE, 2016 January.

[21]Meyer S., Richter S., Timmel S., Glaser M., Werner M., Swatek S. Hagendorf C., 2013. Snail trails: root cause analysis and test procedures. Energy Procedia 38, 498 - 505.

[22]Garni H., Awasthi A., 2017. Techno-economic feasibility analysis of a solar PV grid-connected system with different tracking using HOMER software. In: 5th IEEE International Conference on Smart Energy Grid Engineering, IEEE, 2017, August, pp. 217-222. 